E-ISSN. 2685-7650

Vol. 2 No. 2 (2020), pp 55-65

DOI: https://doi.org/10.33366/jkn.v2i2.47

\title{
Strategi Komunikasi Politik Caleg Perempuan dalam Pileg 2019 di Kota Malang
}

\author{
Firdha Umari ${ }^{1}$, Sulih Indra Dewi ${ }^{2}$ \\ 1,2Program Studi Ilmu Komunikasi, Universitas Tribhuwana Tunggadewi \\ Email: sulih.id@gmail.com
}

\begin{abstract}
This study aimed to find out the political communication strategies of women legislative candidates and what obstacles faced by them. This study used qualitative method and to determine the informants it was wit purposive sampling. Data collection techniques were through interviews and documentation. This study interviewed four woman candidates from different political parties in Malang, and for the first joining a legislative elections. The results of the political communication stretegies were a door to door, approaching religious and structural leaders, used political consultant and had a lot of campaign team were proven to effective in Malang. The obstacles for the women in involving in politics were lack of money and political knowledge and also multiple roles as house wives and ploticians became their internal issue.
\end{abstract}

Keywords: woman representation, political communication, communication strategy

\begin{abstract}
Abstrak: Penelitian ini bertujuan untuk mengetahui bagaimana strategi komunikasi politik calon legislatif perempuan dan hambatan apa yang dihadapi oleh politisi perempuan. Penelitian ini menggunakan metode kualitiatif dan penentuan informan menggunakan purposive sampling. Teknik pengumpulan data melalui tahap wawancara dan dokumentasi. Penelitian ini mewawancarai empat orang calon legislatif perempuan dari partai politik yang berbeda, berdomisili Kota Malang, dan pertama kali maju dalam pemilihan legislatif. Dari hasil penelitian strategi komunikasi politik calon legislatif perempuan menggunakan strategi door to door, pendekatan dengan tokoh agama dan struktural, lalu menggerakkan banyak tim sukses dari rumah ke rumah konstituen dan penggunaan jasa konsultan politik terbukti efektif di Kota Malang. Kendala yang dihadapi oleh para politisi perempuan ini adalah modal ekonomi yang terbatas, minimnya pengetahuan politik serta peran ganda sebagai ibu rumah tangga dan politisi menjadi hambatan internal.
\end{abstract}

Kata Kunci: Keterwakilan Perempuan, Komunikasi Politik, Strategi komunikasi

\section{Pendahuluan}

Tahun 2019 menjadi tahun pertama bagi Indonesia untuk menyelenggarakan pemilihan Presiden (Pilpres) dan Pemilihan Legislatif (Pileg) pada waktu serentak ditanggal 17 April 2019. Tidak hanya itu saja, tahun politik ini menjadi menarik karena peraturan Undang-Undang Nomor 10 Pasal 8 Tahun 2008 yang membahas tentang Pemilihan Umum Anggota Dewan Perwakilan Rakyat, Dewan Perwakilan Rakyat Daerah yang di dalamnya mewajibkan partai politik bisa mengikuti seleksi jika menyertakan sekurang-kurang $30 \%$ keterwakilan perempuan pada kepengurusan partai politik tingkat pusat.

Berpartisipasi di dalam dunia politik dengan dominasi pria menjadi tantangan lebih bagi para perempuan. Hal ini bisa dibuktikan dalam penelitian Mukarom (2008) yang mengemukakan data terkait dominasi laki-laki dalam dunia politik. Semenjak tahun 1950 sampai pemilu 2004, keterwakilan perempuan tidak berubah secara signifikan. Di tahun masa jabatan 1950-1955, 


\section{Jurnal Komunikasi Nusantara}

E-ISSN. 2685-7650

Vol. 2 No. 2 (2020), pp 55-65

DOI: https://doi.org/10.33366/jkn.v2i2.47

keterwakilan perempuan hanya mencapai 9 orang saja atau sekitar 3,8\%, sedangkan laki-laki sebanyak 236 orang atau 96,2\%. Dominasi laki-laki juga terlihat di tahun 2004-2009, kursi parlemen yang diisi perempuan hanya diisi 65 orang atau 11,8\% sedangkan laki-laki mengisi 485 kursi atau 88,2\%.

Dominasi laki-laki dalam politik menunjukkan kuatnya budaya patriarki yang seolah memberi garisan tegas bahwa antara perempuan dan politik, merupakan dua dunia yang berbeda dan tidak mungkin saling bersinergi satu dengan yang lainnya (Wahyudi, 2019). Banyaknya politisi laki-laki yang masih dianggap lebih berkompeten dibanding perempuan bisa menjadi salah satu faktor keterwakilan perempuan rendah. Tidak hanya politisi laki-laki yang menganggapnya demikian, perempuan sendiri menganggap laki-laki lebih berkompeten dibanding perempuan (Susilo \& Nisa, 2019).

Walau dominasi laki-laki yang masih kuat disetiap pemilihan, peraturan perundang-undangan No 10 tahun 2008 meningkatkan keikutsertaan perempuan di dunia politik. Adanya kuota yang tersedia bagi perempuan menjadi salah satu cara meningkatkan keterwakilan perempuan meskipun perjalanan masih panjang (Syafputri, 2017). Secara nasional, dalam RRI.co.id (2018) sesuai dengan data Komisi Pemilihan Umum (KPU), jumlah Caleg perempuan di Indonesia mencapai 3.194 atau sudah memenuhi 30\% seperti yang telah diatur oleh Undang-Undang Pemilu. Angka tersebut meningkat hampir 50\% dari Pemilu 2014. Tidak hanya itu saja, fakta menarik di tahun ini adalah basis pemilih perempuan yang mendominasi. Menurut (Naufal, 2018) berdasarkan data dari KPU, jumlah pemilih perempuan dalam negeri sesuai dengan Data Pemilih Tetap (DPT) Nasional mencapai 92.929.422 dari total 185.732.093 pemilih dalam negeri.

Di Kota Malang, calon legislatif (Caleg) perempuan pada tahun 2019 meningkat sebanyak 6\% jika dibandingkan dengan tahun 2014. Dalam RRI.co.id (2018) di Kota Malang jumlah caleg perempuan ditahun 2014 sebanyak 31\%, sedangkan di tahun 2019 menjadi 37\% atau berjumlah 194 orang dari 529 caleg. Namun, meningkatnya jumlah caleg perempuan tidak berpengaruh terhadap keterwakilan perempuan yang terpilih menjadi dewan. Dari 45 Caleg perempuan, hanya 12 perempuan saja yang berhasil mengisi kursi DPR.

Kondisi ini sudah lebih baik dibanding tahun-tahun sebelumnya. Apalagi kesadaran politisi perempuan di Kota Malang di bidang politik cenderung naik. Pada waktu kampanye, politisi perempuan juga memahami berbagai fenomena kampanye mulai dari konvensional hingga penggunaan hoax di media sosial (Qorib, 2020). Kondisi politik yang demikian membuat perempuan harus memiliki strategi yang efektif untuk memenangkan dirinya. Tentunya ini menjadi kajian yang menarik karena dengan segala macam kendala yang harus dihadapi oleh Caleg perempuan tentunya harus berjuang dengan lebih keras dibandingkan dengan Caleg laki-laki. Dari fenomena yang terjadi di atas, tujuan dari penelitian inilah adalah untuk mengetahui bagaimana strategi komunikasi politik yang diterapkan oleh Caleg perempuan serta hambatan apa yang dihadapi dalam pemilihan legistlatif di Kota Malang di tahun 2019. 


\section{Jurnal Komunikasi Nusantara}

E-ISSN. 2685-7650

Vol. 2 No. 2 (2020), pp 55-65

DOI: https://doi.org/10.33366/jkn.v2i2.47

\section{Metode Penelitian}

Penelitian ini menggunakan metode kualitatif. Menurut Moleong (dalam Arikunto, 2013) sumber data kualitatif adalah tampilan yang berupa kata-kata yang diucapkan secara lisan, gerak-gerik atau perilaku yang dilakukan oleh subjek yang dapat dipercaya, dalam hal ini adalah subjek penelitian (informan) yang berkenaan dengan variabel yang diteliti. Penentuan informan pada penelitian ini menggunakan purposive sampling dengan kriteria antara lain Caleg perempuan Dapil Kota Malang, dengan nomor urut dua atau tiga, dan baru pertama kali mengikuti pemilihan. Informan yang memenuhi kriteria dalam penelitian ini antara lain dua Caleg terpilih yaitu Lelly Theresiyawati (43 tahun) dari Partai Gerindra, dan Nurul Setyowati, SE (52 tahun) dari PDIP. Sedangkan informan lainnya adalah Hizbiyatul Islamiyah, S.Ars (27 tahun) dari PKS, dan Siska Arichlawati, Amd.RMK (25 tahun) dari PAN. Pengumpulan data dalam penelitian ini adalah melalui wawancara dan dokumentasi kegiatan Caleg perempuan selama masa kampanye baik secara langsung maupun melalui media sosial dan media massa. Sedangkan teknik analisis data yang digunakan pada penelitian ini menggunakan metode Miles And Hubberman (dalam Sugiyono, 2012) yaitu reduksi data, penyajian data dan penarikan kesimpulan.

\section{Hasil dan Pembahasan}

\section{Strategi Komunikasi Politik Caleg Perempuan dalam Pileg 2019 di Kota Malang}

Dalam strategi Komunikasi Politik Caleg Perempuan dalam Pileg 2019 di Kota Malang menurut Gregory yang dikutip dari Venus (2019) terbagi dalam beberapa bagian. Berikut strategi yang dilakukan oleh Caleg perempuan:

\section{a. Analisis Masalah}

Sebelum melakukan kampanye, informan melakukan analisis masalah apa yang ada di dalam masyarakat, bagaimana karakteristik konstituen dan cara apa yang bisa dilakukan untuk bisa dekat dengan mereka. Dalam Analisis Masalah terdapat analisis PEST (Political, Economic, Social, Technology) yang bisa dilakukan oleh Caleg. Informan pertama menganalisis terkait politik dan sosial yang terjadi di masyarakat. Dirinya menganalisis terkait kurangnya peran perempuan dalam dunia politik sehingga dirinya maju untuk mewakili suara perempuan. Ditambah lagi dengan kejadian pelecehan seksual terhadap perempuan yang marak terjadi di masyarakat. Informan pertama ingin menjadi penjembatan untuk kebijakan pemerintah ketika terpilih sebagai wakil perempuan. Sedangkan informan kedua lebih berfokus pada nilai ekonomi dan sosial karena menganalisis tata ruang Kota Malang dengan latar belakangnya yang pernah bekerja di bagian perizinan iklan di Surabaya. Dengan penataan tata reklame iklan yang bagus dengan perpaduan tata pohon yang memadai bisa membuat Kota Malang lebih meningkat dari sisi ekonomi dan keindahannya.

Informan ketiga, menganalisis permasalahan ekonomi dan sosial dengan skala dapilnya seperti pemerataan infrastruktur jalan yang belum merata di daerah Kedungkandang, banyaknya pengangguran dan juga UKM yang stagnan. Dengan tingginya pengguna gadget, sangat 


\section{Jurnal Komunikasi Nusantara}

E-ISSN. 2685-7650

Vol. 2 No. 2 (2020), pp 55-65

DOI: https://doi.org/10.33366/jkn.v2i2.47

disayangkan potensi UKM yang kurang diberdayakan dan pengangguran masih tinggi ditempat dapilnya. Lalu informan keempat yang lebih menganalisis permasalahan ekonomi dan sosial yang terjadi pada pekerja kesehatan. Dengan latar belakang pekerjaan yang sama, informan keempat menganalisis tidak seimbangnya gaji yang didapat dengan jam kerja dan resiko yang dilakukan. Informan keempat berusaha mewakili teman-teman sejawatnya. Tidak hanya itu, informan keempat juga menyoroti permasalahan money politics yang ada di tengah konstituen. Tidak jarang konstituen melihat berapa uang yang dipunyai oleh caleg yang sedang berkampanye.

Sesuai dengan komunikasi politik menjadikan analisis masalah sebagai langkah awal sebelum melakukan suatu perencaanaan. Namun sangat disayangkan, analisis yang dilakukan oleh para informan ini hanya satu dari empat informan yang menyinggung tentang hak perempuan dan anak. Padahal menurut Mukarom (2008) strategi yang bisa dilakukan oleh perempuan adalah dengan menerapkan pengarusutamaan gender, aksi afirmatif, pendidikan politik untuk perempuan dan pendidikan kewarganegaraan kepada perempuan. Hal ini dikarenakan isu terkait perempuan dianggap kurang menarik dibandingkan dengan isu-isu pengangguaran atau kemiskinan (Handoko, 2009).

\section{b. Tujuan}

Setelah analisis masalah, disinilah para caleg menentukan tujuan. Penentuan tujuan juga harus realistis agar mempunyai arah yang terfokus saat proses pencapainya. Informan pertama, kedua, ketiga dan keempat tentu saja bertujuan untuk mengajak konstituen memilih mereka di hari pemilihan. Menarik untuk diperhatikan bahwa informan pertama, kedua dan ketiga berupaya mengajak konstituen untuk memilih Calon Presiden (Capres) dan Calon Wakil Presiden (Cawapres) yang diusung. Informan pertama dan ketiga sebagai pengusung Capres dan Cawapres nomor 2, Prabowo-Sandi. Begitu pula informan kedua, bertujuan untuk mengajak konstituen untuk memilih Capres dan Cawapres nomor urut 01, Jokowi-Amin. Para informan menggunakan cara tersebut untuk memaksimalkan cara kerja ketika berkampanye dengan melihat konstituen akan memilih Capres dan Cawapres yang mana.

Tidak hanya itu saja, informan ketiga juga memberikan informasi terkait program kampanye PKS kepada konstituen. Sedikit berbeda, informan keempat bertujuan mengubah pola pikir konstituen ketika berkampanye dengan memberikan edukasi tentang politik. Dari sini kita bisa melihat tujuan yang beragam dari banyak informan namun yang bisa digarisbawahi adalah strategi paling efektif yang bisa dilakukan berdasarkan tujuan Caleg adalah mengidentifikasi konstituen mengusung Capres dan Cawapres yang mana.

Ini juga membuktikan teori penetrasi sosial oleh Irwin Altman dan Dalmas Taylor bahwa manusia dapat mengungkapkan diri satu sama lain termasuk komunikasi antarpersonal melalui penetrasi atau penyusupan sosial ke dalam pribadi yang lain (Liliweri, 2014). Penyusupan tersebut bisa berdasarkan informansi yang didapatkan baik secara mendalam atau permukaan saja. Jadi, ketika para informan menargetkan suatu konstituen menggunakan penetrasi sosial 


\section{Jurnal Komunikasi Nusantara}

E-ISSN. 2685-7650

Vol. 2 No. 2 (2020), pp 55-65

DOI: https://doi.org/10.33366/jkn.v2i2.47

dengan melihat informasi permukaan saja seperti calon presiden siapa yang akan dipilih maka akan lebih efisien dan efektif.

\section{c. Identifikasi dan Segmentasi Sasaran Kampanye}

Menentukan identifikasi dan segmentasi sasaran kampanye adalah bagian yang sangat penting. Hal tersebut dikarenakan agar tidak serabutan orang yang dituju dengan waktu yang terbatas ketika berkampanye. Informan pertama mengaku lebih menyasar kepada perempuan. Tidak ada target untuk batasan usia, agama, latar belakang pendidikan atau pekerjaan. Dua belas kelurahan yang ada di Kecamatan Lowokwaru disasar dan diutamakan dengan basis suara Prabowo-Sandi. Lalu informan kedua, menyasar kepada konstituen $70 \%$ perempuan dan $30 \%$ laki-laki, berusia 30-40, dan lebih memaksimalkan basis suara PDIP dari 12 kelurahan yang ada di Kecamatan Lowokwaru.

Sedangkan informan ketiga lebih menargetkan pada anak-anak muda sebagai sasaran utama dari usia 17-35 tahun, beragama Islam dan menyasar empat dari 12 kelurahan yang ada di Kecamatan Kedungkandang dan memaksimalkannya dengan mendekati konstituen yang memilihi Prabowo-Sandi. Lalu, informan keempat sendiri menyasar konstituen $60 \%$ perempuan dan 40\% laki-laki. Ia juga menarget usia muda dari 17-40 tahun menjadi sasaran utamanya. Untuk segmentasi agama tertentu tidak ada, namun ia lebih menyasar kepada konstituen yang berlatar belakang dan bekerja di bidang kesehatan.

Informan pertama dan kedua menyasar seluruh kelurahan di dapilnya dan memaksimalkan basis-basis suara yang ada sesuai dengan segmentasi masing-masing terbukti efektif. Sedangkan informan ketiga sudah sangat terstruktur namun yang disasar hanya menyasar empat kelurahan saja. Sedangkan untuk informan keempat jenjang yang jauh dan bertujuan kepada konstituen yang bekerja di bidang kesehatan terbukti ti dak efektif.

Dari informasi yang didapatkan diatas, penentuan segmentasi yang jelas akan sangat membantu untuk mengetahui cara apa yang akan dilakukan dalam proses berkampanye. Dengan waktu kampanye yang singkat dan dengan tujuan untuk mengumpulkan suara yang banyak maka penentuan konstituen yang lebih terstruktur akan lebih memudahkan para Caleg.

\section{d. Membentuk Pesan}

Secara gamblang informan pertama dan informan kedua menjelaskan tidak mempunyai pesan gagasan atau visi misi ketika berkampanye. Kedua informan menjelaskan bahwa program-program nanti baru akan ada ketika sudah terpilih. Informan pertama menjelaskan, Ia meyakinkan konstituen dengan memilihnya maka dirinya akan membawa aspirasi masyarakat jika terpilih selama 5 tahun kedepan. Terutama dirinya akan membawa aspirasi anak dan perempuan yang memang harus dilindungi.

Hal senada juga disampaikan oleh informan kedua yang meyakinkan konstituen bahwa dengan memilihnya, dirinya akan menjadi penyambung informasi langsung di parlemen. 


\section{Jurnal Komunikasi Nusantara}

E-ISSN. 2685-7650

Vol. 2 No. 2 (2020), pp 55-65

DOI: https://doi.org/10.33366/jkn.v2i2.47

"Terus terang ketika saya berkampanye saya tidak menjual program karena saya orang baru. Program itu ada kalau kita sudah menjadi dewan. Makanya saya juga nggak terlalu muluk-muluk untuk menguatarakan program. Saya ngga mau ada omongan janjinya besar tapi tidak dilakukan, malah jadi boomerang buat saya." (wawancara dengan informan kedua)

Sedangkan informan ketiga dengan analisis masalah yang ada dan dengan segmentasi yang telah ditetapkan, ia memiliki visi misi yang dinamai 8 komitmen dan misi perjuangan. Sedangkan untuk informan keempat, mempunyai visi perubahan mindset yang ada di masyarakat terkait money politcs dan edukasi yang merata terkait politik kepada masyarakat. Selain itu, visi dan misi oleh informan keempat adalah meningkatkan elektabilitas masyarakat dan membangun masyarakat yang sadar politik.

Dari informan pertama dan kedua yang terpilih, tidak adanya visi misi atau gagasan yang dibawa ketika berkampanye menunjukkan ada masalah yang lebih besar selain kurangnya pengetahuan politik dari caleg. Keterbatasan pengetahuan dalam dunia pilitik berkaitan dengan sosialisasi politik yang selama ini dilakukan baik oleh partai politik maupun media. Sosialisasi ini seakan mengarahkan perempuan untuk mendapatkan status tertentu tanpa usahanya sendiri (ascribe status) (Mukarom, 2008). Hal ini menyebabkan caleg perempuan tidak memiliki pesan politik yang kuat dalam bentuk visi dan misi.

\section{e. Strategi}

Strategi yang dilakukan oleh informan pertama dan kedua sama, memaksimalkan metode door to door atau dari pintu ke pintu rumah konstituen. Informan pertama dibantu oleh timses untuk berkampanye dari rumah ke rumah, mendekati tokoh agama dan struktural, membuat beragam Alat Peraga Kampanye (APK) seperti banner, pamflet, kartu nama, kaos, kalender sebanyak 2000 lembar, 5000 alat tiruan surat suara, dan bahkan minuman air berukuran gelas untuk dibagikan kepada konsituen. Informan pertama juga membuat komunitas yang bergerak di bidang sosial dari tahun 2016. Komunitas ini menjadi lumbung suara informan pertama dan ia juga berkumpul dengan 50 konstituen setiap minggunya untuk disambut dirumahnya.

Informan kedua juga memaksimalkan metode door to door dan juga menggunakan jasa konsultan politik. Menargetkan 5 rumah setiap hari dan dibantu oleh timses sebanyak 135 orang dan mendekati tokoh struktural dan agama yang responsif kepada PDIP. Beragam APK seperti mencetak 3000 banner, baliho berukuran 4x6 sebanyak 10 buah, kartu nama, 2000 baju, dompet, gantungan kunci 150 buah, dan kalender 1500 lembar dibagikan ke konstituen.

Sedikit berbeda, informan ketiga mempunyai strategi kampanye door to door sebanyak $60 \%$ dan media sosial sebanyak 40\%. Dirinya juga mendekati tokoh agama dan struktural, berkampanye melalui media massa TV, dan bergerak dibantu oleh 50 tim sukses. Selain itu informan ketiga membuat 200 list prioritas dari suara aman yang jika nanti terpilih akan mendapatkan informasi terkait program pemerintah. Informan ketiga membuat 7 buah baliho, banner berjumlah 42 yang tersebar di 4 dapil, dan 150 alat tiruan surat suara. 


\section{Jurnal Komunikasi Nusantara}

E-ISSN. 2685-7650

Vol. 2 No. 2 (2020), pp 55-65

DOI: https://doi.org/10.33366/jkn.v2i2.47

Sedangkan informan keempat membagi 50\% kampanye dengan door to door dan $50 \%$ untuk media sosial. Informan keempat menjelaskan dirinya bergerak pada awalnya dengan tim sukses dan juga mendekati tokoh agama dan struktural, namun karena permasalahan biaya dirinya mengaku timsesnya tidak berjalan dengan maksimal. Maka dari itu dirinya memanfaatkan sosial media sebagai alat kampanyenya. Dirinya mencetak banner sebanyak 7 buah, 1000 lembar stiker, dan 1000 lembar kalender ketika berkampanye secara door to door.

Dari data yang disampaikan oleh informan pertama dan kedua yang secara maksimal menggunakan metode door to door ternyata sangat efektif di Kota Malang. Metode ini termasuk komunikasi interpersonal yang merupakan proses penyampaian pesan secara empat mata atau diartikan sebagai komunikasi "satu-kepada-satu" (Pureklolon, 2016). Hal ini akan memberikan modal sosial yang cukup bagi caleg perempuan untuk bisa mendapatkan trust dari konstituennya (Siswanto, 2019).

Informan ketiga dan keempat yang menggunakan metode kampanye di sosial media ternyata masih belum begitu efektif di Kota Malang. Berdasarkan dari observasi akun media sosial kedua informan menunjukkan bahwa pesan yang disampaikan di media sosial sekedar informasi tentang caleg secara pribadi dan tidak banyak berbicara tentang program maupun keunggulan caleg. Frekuensi update juga jarang, sehingga terlihat media ini pemanfaatannya kurang maksimal.

Sedangkan informan kedua selain memiliki tim sukses juga menggunakan konsultan politik. Konsultan politik dinilai sangat dibutuhkan untuk memberikan nasihat dan pendampingan khusus kepada peserta pemilih (Indrawan \& Efriza, 2018). Terbukti, informan ketiga mendapatkan suara mencapai tiga ribu lebih dan menjadi legislatif perempuan terpilih. Namun, tentunya biaya politik yang dikelaurkan juga lebih besar daripada caleg perempuan lainnya.

\section{f. Alokasi Waktu}

Alokasi waktu yang dimaksimalkan oleh informan pertama, informan kedua dan informan keempat adalah 8 bulan masa kampanye. Berbeda dengan informan ketiga sekitar 6 bulan. Sedangkan alokasi dana yang dikeluarkan oleh informan pertama sebanyak 100 juta Rupiah. Informan kedua sebanyak 60-75 juta Rupiah. Informan ketiga sebanyak 15 juta Rupiah dan informan keempat sebanyak 10 juta Rupiah. Dana tersebut berasal dari dana pribadi yang dikeluarkan oleh para informan.

\section{g. Evaluasi}

Evaluasi setelah pemilihan juga dilakukan oleh seluruh informan. Informan pertama dan kedua mengaku lebih mengevaluasi timsesnya. Sedangkan informan ketiga mengevaluasi persiapan yang harus jauh-jauh hari sebelum masa kampanye dan persiapan dana. 


\section{Jurnal Komunikasi Nusantara}

E-ISSN. 2685-7650

Vol. 2 No. 2 (2020), pp 55-65

DOI: https://doi.org/10.33366/jkn.v2i2.47

"Walau saya sendiri berusaha untuk mengkampanyekan supaya ayolah maju jadi caleg itu ngga harus dana banyak utk menghindari korupsi-korupsi tetapi publikasi dan maintenance tim penggerak ini juga butuh dana." (wawancara dengan informan ketiga).

Hal senada juga disampaikan oleh informan empat yang juga mengevaluasi masalah dana yang kurang dan waktu yang terbatas karena pada saat kampanye anaknya masih harus mendapatkan ASI dan kesana kemari ketika suami bekerja dan waktu suami pulang, dirinya juga kembali untuk keluarga.

Dari penjabaran data diatas, strategi komunikasi politik yang efektif di Kota Malang masih bersifat konvensional. Pesan atau gagasan politik dari informan tidak begitu penting asalkan para informan atau timnya hadir ke rumah konstituen. Metode dari pintu ke pintu rumah konstituen oleh informan satu dan kedua terbukti efektif daripada berkampanye melalui sosial media. Tidak hanya itu saja, hal tersebut juga didukung oleh modal ekonomi. Strategi kampanye bisa berjalan efektif dan menghasilkan suara yang banyak ketika dana yang dipunyai informan besar. Dana dapat dialokasikan mulai dari menggunakan konsultan politik yang bisa membantu apa yang bisa dilakukan oleh informan, dana untuk publikasi segala macam atribut kampanye dan merawat tim sukses yang berjalan dalam proses kampanye. Dari dua orang informan yang gagal melaju menjadi anggota dewan adalah kurangnya dana dan persiapan Caleg muda yang memang harus disiapkan secara matang.

\section{Kendala Penerapan Strategi Komunikasi Politik}

Internal

Kendala internal yang dihadapi oleh informan pertama, informan kedua dan informan keempat adalah keluarga. Sebagai caleg yang juga ibu rumah tangga, tentu saja ketika berkampanye harus menyelesaikan tugas rumah terlebih dahulu. Informan ketiga yang bekerja sebagai kepala sekolah sebuah TK juga harus pintar membagi waktu sebagai kepala sekolah dan anak dalam sebuah keluarga. Peran ganda sebagai ibu rumah tangga dan politisi menjadi kendala tersendiri.

\section{Eksternal}

Informan pertama, kedua, ketiga dan keempat merasakan kendala yaitu keluarnya anggota tim sukses dari tim kampanyenya. Dengan alasan yang sama, anggota tim sukses ini mencari calon lain yang mempunyai uang yang lebih banyak atau bekerja tidak maksimal karena para caleg ini tidak menggunakan praktik money politics. Sedangkan informan ketiga dan keempat mengaku kendala yang dihadapinya adalah masalah dana. Informan ketiga mengaku dana ini sangat membantu untuk proses publikasi dan juga merawat tim sukses. Senada, informan keempat juga mengaku dana sangat dibutuhkan untuk membuat tim sukses mengawal suara agar aman saat penghitungan suara. Sehingga modal finansial yang menjadi faktor yang cukup berpengaruh terhadap keberhasilan perempuan untuk terjuan ke dunia politik. Informan 


\section{Jurnal Komunikasi Nusantara}

E-ISSN. 2685-7650

Vol. 2 No. 2 (2020), pp 55-65

DOI: https://doi.org/10.33366/jkn.v2i2.47

pertama dan informan kedua yang berhasil menjadi caleg terpilih menghabiskan dana antara 65-100 juta Rupiah.

Peran partai politik juga terlihat tidak terlalu dominan dalam proses perekrutan maupun pelatihan caleg perempuan. Bahkan salah satu informan mengaku dirinya sekedar menggantikan caleg lain yang terkena kasus sehingga tidak bisa maju dalam pemilihan legislatif. Pemimpin laki-laki dari partai memiliki mempunyai pengaruh yang tidak proporsional terhadap politik partai, khususnya dalam hal gender (Parawansa, 2013), sehingga perempuan tidak memperoleh banyak dukungan dari partai- karena struktur kepemimpinannya didominasi oleh kaum laki-laki. Menurut Meutya Viada Hafid, Anggota Komisi I DPR (dalam Dewi \& Aminulloh, 2014), partai politik menempatkan caleg perempuan masih sebatas sebagai pemenuhan persyaratan KPU semata, bukan didasarkan pada kebutuhan politisi perempuan di parlemen nantinya sehingga masih banyak partai politik yang mengisi caleg nomor urut pertama pada dapil tertentu, non-perempuan.

Dari uraian di atas, modal berupa pengetahuan politik yang seharusnya menjadi modal utama ternyata dalam praktinya menjadi modal nomor dua setelah modal ekonomi. Biaya politik yang mahal mengakibatkan kualitas caleg perempuan legislatif juga menjadi nomor dua jika berbicara tentang dana pribadi. Tidak jarang posisi kepala rumah tangga atau yang berpenghasilan di dalam sebuah keluarga adalah suami atau ayah perempuan. Modal penting lainnya yang harus dimiliki oleh politisi perempuan yaitu modal individu, modal sosial, dan modal strategi yang ketiganya berperan penting dalam menyukseskan kontestasi politik perempuan (K. H. Dewi et al., 2018).

Berdasarkan penelitian terkait dengan partisipasi perempuan dalam politik di beberapa negara berkembang, ada tiga tantangan utama yang dihadapi oleh perempuan. Yang pertama adalah adalah supply and demand. Supply yang berarti faktor-faktor yang prinsipal yang mempengaruhi kualitas perempuan dan demand adalah faktor-faktor institutional dan politis yang terkait dengan sistem rekrutmen partai. Sedangkan faktor yang kedua adalah masalah sosialisasi politik yang selalu menganggap bahwa kesuksesan perempuan adalah karena bantuan pihak lain dan yang ketiga adalah faktor situasional yang mencakup masalah keibuan (Mukarom, 2008). Ketiga keterbatasan tersebut juga dihadapi oleh para informan. Misalnya saja bagaimana para informan ini harus berperan ganda sebagai ibu, pekerja dan juga politisi.

\section{Kesimpulan}

Strategi komunikasi politik caleg perempuan di kota Malang yang bisa berjalan cukup efektif adalah door to door atau dari pintu ke pintu rumah konstituen. Komunikasi interpersonal terbukti masih menjadi komunikasi yang cukup efektif dibandingkan dengan komunikasi massa dan media sosial. Tim sukses dan konsultan politik mempunyai dampak yang besar dalam membangun komunikasi politik dan strategi politik caleg. Jasa konsultan dalam komunikasi politik di Kota Malang juga berpengaruh untuk menentukan pesan, sasaran, dan saluran apa untuk menyebarluaskan terkait pencalonan. Namun, tentu saja modal politik berupa dana juga masih menjadi hal yang tidak bisa dinomor duakan. Terlepas dari money politics terhadap 


\section{Jurnal Komunikasi Nusantara}

\section{E-ISSN. 2685-7650}

Vol. 2 No. 2 (2020), pp 55-65

DOI: https://doi.org/10.33366/jkn.v2i2.47

konstituen, dana yang banyak sangat bergunan untuk publikasi seperti membuat beragam APK dan untuk merawat tim sukses yang telah membantu selama kampanye berjalan.

Kendala yang dialami oleh para caleg perempuan ini adalah dana yang besar untuk bisa menjadi politisi perempuan yang terpilih. Mahalnya biaya politik juga memengaruhi suara yang bisa didapatkan. Dana yang besar tentu saja bisa memaksimalkan publikasi agar banyak konstituen yang tahu dan menggerakan banyak tim sukses. Hal tersebut bisa dilakukan jika dana yang dimiliki mencukupi. Selain itu peran caleg perempuan ganda sebagai ibu dan juga politisi yang maju sebagai caleg juga menjadi kendala. Pembagian waktu yang harus bisa dilakukan secara maksimal sebagai orang tua dan caleg yang sedang berkampanye menjadi penghambat. Sebenarnya hambatan-hambatan tersebut tidak harus dialami oleh perempuan apabila ada dukungan sosial dan partai politik. Perempuan harus bekerja ekstra keras untuk bisa membuktikan dirinya mampu dan memiliki kapasitas dalam politik dan diterima oleh partai politik yang didominasi oleh laki-laki (Budiarti, 2011). Keterbatasan partisipasi politik perempuan akan berdampak besar terhadap upaya pengembangan masyarakat termasuk upaya pemberdayaan perempuan.

\section{Daftar Pustaka}

Arikunto, S. (2013). Prosedur Penelitian Suatu Pendekatan Praktik. Jakarta: PT Asdi Mahasatya.

Budiarti, A. P. (2011). Bayang-bayang Afirmasi Keterwakilan Perempuan di Parlemen Indonesia. Jurnal Studi Politik, 1(2), 97-113.

Dewi, K. H., Kusumaningtyas, A. N., Ekawati, E., \& Soebhan, S. R. (2018). Modal, Strategi dan Jaringan Perempuan Politisi dalam Kandidasi Pilkada Langsung. Jurnal Penelitian Politik, 15(2), 267-288.

Dewi, S. I., \& Aminulloh, A. (2014). Perubahan Kesadaran Politik Perempuan Pada Pemilu 2014. Prosiding Seminar Komunikasi Politik.

Handoko, T. H. (2009). Manajemen. Yogyakarta: BPFE-Yogyakarta.

Indrawan, R. M. J., \& Efriza, E. (2018). Membangun Komponen Cadangan Berbasis Kemampuan Bela Negara Sebagai Kekuatan Pertahanan Indonesia Menghadapi Ancaman NIR-MILITER. Jurnal Pertahanan \& Bela Negara, 8(2), 21-40. https://doi.org/10.33172/jpbh.v8i2.395.

Liliweri, A. (2014). Komunikasi Antar Personal. Jakarta: Kencana Prenamedia.

Mukarom, Z. (2008). Perempuan dan Politik: Studi Komunikasi Politik tentang Keterwakilan Perempuan di Legislatif. Mediator: Jurnal Komunikasi, 9(2), 257-269. https://doi.org/10.29313/mediator.v9i2.1125.

Naufal, D. (2018). Romantisme Perempuan dan Politik. News.Detik.Com. https://news.detik.com/kolom/d-4320716/romantisme-perempuan-dan-politik.

Parawansa, K. I. (2013). Studi Kasus: Hambatan terhadap Partisipasi Politik Perempuan di Indonesia. Www.Idea.Int. www.idea.int/publications/wip/upload/CS-Indonesia.pdf.

Pureklolon, T. T. (2016). Komunikasi Politik Mempertahankan Integritas Akademisi, Politikus dan Negarawan. Jakarta: PT Gramedia Pustaka Utama.

Qorib, F. (2020). Persepsi Hoax Politik Caleg Perempuan pada Pemilihan Umum Legislatif 2019 di Kota Malang. Jurnal Warta ISKI, 3(1), 12-23. 


\section{Jurnal Komunikasi Nusantara}

E-ISSN. 2685-7650

Vol. 2 No. 2 (2020), pp 55-65

DOI: https://doi.org/10.33366/jkn.v2i2.47

RRI.co.id. (2018). Keterwakilan Perempuan di Malang dalam Pileg 2019 Cukup Tinggi. (http://rri.co.id/post/berita/575277/pemilu_2019/keterwakilan_perempuan_di_ malang_pada_pileg_2019_cukup_tinggi.html, diakses pada 11 Mei 2019).

RRI.co.id. (2018). Koalisi Perempuan Indonesia Jatim Dorong Keterwakilan Perempuan di Legislatif”. (http://rri.co.id/surabaya/post/berita/660274/politik_-_ pemerintahan/koalisi_perempuan_indonesia_jatim_dorong_keterwakilan_pere mpuan_di_legislatif, diakses 16 April 2019).

Siswanto. (2019). Modal Sosial dalam Komunikasi Politik. MetaCommunication: Journal Of Communication Studies, 4(2), 259-265.

Sugiyono. (2012). Metode Penelitian Kuantitatif, Kualitatif dan R\&D. Bandung: Alfabeta.

Susilo, M. E., \& Nisa, N. L. (2019). Strategi Komunikasi Politisi Perempuan. Jurnal Ilmu Komunikasi, 16(1), 54-65. https://doi.org/10.31315/jik.v16i1.2682.

Syafputri, E. (2017). Keterwakilan Perempuan di Parlemen: Komparasi Indonesia dan Korea Selatan. Global South Review, 1(2), 165-175. https://doi.org/10.22146/globalsouth.28839.

Venus, A. (2019). Manajemen Kampanye Panduan Teoretis dan Praktis Dalam Mengefektifkan Kampanye Komunikasi Publik. Bandung: PT Remaja Rosdakarya Offset.

Wahyudi, V. (2019). Peran Politik Perempuan dalam Persfektif Gender. Politea : Jurnal Politik Islam, 1(1), 63-83. https://doi.org/10.20414/politea.v1i1.813. 